\title{
From phenology models to risk indicator analysis
}

\author{
Márta Ladányi ${ }^{1}$, Szilvia Persely ${ }^{2}$, József Nyéki $^{3}$, Zoltán Szabó ${ }^{4}$
}

\section{N F O}

Received 19 Oct. 2010

Accepted 24 Nov. 2010

Available on-line 30 Nov. 2010

Responsible Editor: K. Rajkai

Keywords:

phenology model, weather indicator, climate change,

climate model, sour cherry

\begin{abstract}
$\underline{\text { A B S T R A C T }}$
In this paper we outline a phenology model for estimating budbreak and full bloom starting dates of sour cherry on the effective heat sums with reasonable accuracy. With the help of RegCM3.1 model the possible trends of the phenology timing in the middle of the 21 st century the shift of 12-13 days earlier budbreak and 6-7 days earlier of full bloom due to the warmer weather conditions can be clearly indicated. For the climatic characterization of sour cherry bloom period in between 1984-2010 and for the description of the expected changes in this very sensitive period of sour cherry with respect to the time slice 2021-2050, we introduce seven climatic indicators as artificial weather parameters such as the numbers of days when the temperature was under $0^{\circ} \mathrm{C}$ and above $10^{\circ} \mathrm{C}$, the numbers of days when there was no and more than $5 \mathrm{~mm}$ precipitation as well as the absolute minimum, the mean of minimum and the mean of maximum daily temperatures. We survey the changes of the indicators in the examined period (19842010) and, regarding the full bloom start model results, we formulate the expectations for the future and make comparisons.
\end{abstract}

\section{Introduction}

The closing decades of the $20^{\text {th }}$ century and the early years of the present century in Hungary were unusually warm with several extreme events (droughts, storms, hails, frosts, floods etc.). Living systems have their own capacity and speed of adaptation to the particular changes they face in their environment. In case the changes are small and occur slowly enough, the success of adaptation is almost sure. Estimations of warming by about $2-3^{\circ} \mathrm{C}$ or more in a century or more may seem to be not too much, however, a change of this speed can be too fast to keep up with (Houghton, 2009). Of course, estimations regarding the near or far future are companied with considerable uncertainties which are caused by imperfect knowledge of way and scale of climate change and its direct and indirect impacts. However, modeling and simulating climate change impacts has of great importance for having a sight of the possible future in order to be able to prepare.

In this work we focus on a method with which we can characterize the expected changes of a very sensitive period of sour cherry, namely bloom and ten days before.

First we introduce a phenology model to estimate the starting dates of budbreak and full bloom. To learn the characteristics and the way of change of the early vegetation period of sour cherry is very important because the success of production together with the one of plant protection and technology techniques scheduling is depending mainly on phenological information. Moreover, several risk factors such as frost, infection, insufficient pollination etc. can be traced back to the connection of weather and

\footnotetext{
${ }^{1}$ Márta Ladányi

Corvinus Unversity of Budapest, 1118 Budapest, Villányi út 29., Hungary

marta.ladanyi@uni-corvinus.hu

2,3,4 Szilvia Persely, József Nyéki, Zoltán Szabó

Institute for Extension and Development, University of Debrecen, 4032 Debrecen, Böszörményi út 138., Hungary

suto@agr.unideb.hu

nyeki@agr.unideb.hu

zszabo@agr.unideb.hu
}

ISSN 2061-862X http://www.magisz.org/journal

Márta Ladányi, Szilvia Persely, József Nyéki, Zoltán Szabó: From phenology models to risk indicator analysis 
phenological timing. This kind of research is of even greater importance nowadays when usual phenological timing is changing because of climate change.

The model is based on the effective heat sums calculated from historical data referring to 1984-2010 and it was calibrated and validated for the most important three sour cherry varieties in Hungary, grown at Újfehértó ('Ujffehértói fürtös', 'Kántorjánosi' and 'Debreceni bötermö').

Having a model in hand which allows relatively well-reliable estimations for the starting dates of budbreak and full bloom, we can go on with asking what predictions can be made if we change historical weather data to those of regional climate model outputs. Keeping in mind that the model was calibrated for past and present observed and well-detected circumstances and there is some uncertainty if it is suitable to apply for future estimations, we make an attempt. The basis of our hope not to err too much is that the temporal distance of calibration and application time slices is not too long and that regionally downscaled ocean-surface climate change models of our days are giving quite adequate estimations for the near future.

Analyzing the output of the phenology model run with regional climate model estimations we can learn the expected phenological shift in the future which can be considered as the response of the plant to its changing climate.

Going back to our point, in order to learn the climatic characteristics of sour cherry bloom, we introduce climatic indicators. Climatic indicators are artificial parameters in the form of functions of simple weather parameters (temperature, precipitation etc.). The reason of using climatic indicators is the fact that the responses of the plants to climate change can be formulated as to be tightly correlated with the changes of the values of suitable weather indicators. Climatic indicators, therefore, are easy to be related to different kinds of risk. If we analyze the values and distribution of indicators in time and space, they may signalize the risk of several types. Thus, the analysis of climatic indicators may serve the analysis of climate change impact.

For that purpose, data of seven indicators have been traced in bloom and pre-bloom period:

- the number of frosty days,

- the absolute minimum temperature $\left({ }^{\circ} \mathrm{C}\right)$,

- the mean of minimum temperatures $\left({ }^{\circ} \mathrm{C}\right)$,

- the number of days when daily means are above $10^{\circ} \mathrm{C}$,

- the mean of maximum temperatures $\left({ }^{\circ} \mathrm{C}\right)$,

- the number of days without precipitation,

- the number of days when precipitation is more than $5 \mathrm{~mm}$.

We examine the changes of the above indicators in the examined period (1984-2010).

As a next step, we take the observed starting and ending dates of bloom in time interval 1984-2010, calculate and fix the average endpoints of them (say: base bloom). Supposed that the phenology model predictions of the full bloom starting dates can be applied, according to its prediction we shift the fixed base bloom period. The shifted period can be considered as analogous full bloom period. Then, regarding the time slice 2021-2050 the same seven indicators are calculated for the base bloom period and for the shifted analogous bloom period, together with their 10-day pre-bloom-period, based on the regional climate model output data.

The results of the future expectations were compared to the ones of the historical data with ANOVA followed by Dunnett or Games-Howell post hoc tests. It was also tested whether the differences between the predictions for the base bloom and analogous bloom periods are significant or not. Significant differences were detected if $\mathrm{p}<0.05$. 


\section{Materials and methods}

\subsection{Model-based estimation of the starting dates of budbreak and full bloom}

Since the middle of the 18th century several investigations have been made on the relationship of phenology and meteorological conditions (Reaumur, 1735). Experimental and simulation work on tree phenology has provided much information on budbreak and bloom start. The topic has its revival as the need of accurate predictions of phenology has become of great importance due to climate change (Haenninen, 1991, Kramer, 1994, Kramer et al., 1996., Chuine, 2000, Chuine et al., 1998, 1999, 2003, Carter et al., 2007).

The method of calculating the sum of effective daily mean temperatures as 'growing degree days', is based on many experiments that the plants are able to utilize the temperature above a lower and under an upper base temperature after the chilling effect during the dormancy (Spano et al., 2002, Cesaraccio et al., 2004). However, the start and end point of date of dormancy is still hard to define as it is actually a gradually changing state from endodormancy to ectodormancy. The situation is usually interpreted such that after a given date the daily mean temperature above a lower and under an upper base temperature is accumulated up to a certain critical value (Moncur et al., 1989). As the critical value has been reached the model signalizes the budbreak (Carbonneau et al., 1992, Jones, 2003, Jones et al., 2005). The lower and upper base temperatures are regularly determined by optimization while the start of heat accumulation is fixed at a date when the previous vegetation period has been ended and the new has not started yet, in most cases with the first of January (Riou, 1994, Bindi et al., 1997 a,b). This kind of budbreak models can be improved if the chilling effect during the dormancy is also taken into consideration, or, at least the end of endodormancy is estimated.

A full bloom model can be connected to a budbreak model with calculating an extra heat sum which follows the budbreak. The lower and upper base temperatures can again be optimized particularly for full bloom.

The accumulation of heat sum can be described with several types of functions. The decision is mainly depending on the accuracy and relevancy of data (Oliveira 1998, Riou, 1994), thus the models can be quite different. However, excessively sophisticated models need the estimation of a host of parameters. At the same time, the models can become utterly sensitive and in spite of that they may not come up to the accuracy expected (Riou, 1994, Cortázar-Atauri et al., 2009).

As we faced data scarcity problems, our model is a relatively simple one, nevertheless, it is sufficiently accurate and suitable to predict the date of budburst together with full bloom starting dates for the three most important sour cherry varieties grown in Hungary, namely Újfehértói fürtös' (Uf), 'Kántorjánosi' $(\mathrm{Kj})$ and 'Debreceni bötermö' (Db). Instead of calculating the chilling effect, we have chosen a term which coincides with the end of endodormancy or the beginning of ectodormancy, respectively. For that purpose, a linear accumulation function was applied where the daily mean temperatures above the optimized lower and upper a base temperatures were calculated from an extra optimized parameter, namely the statistically estimated starting date of ectodormancy.

For each variety $i$ in year $j$ we calculated the sum of daily mean temperatures $\left(T_{\text {aver, }, j}\right)$ taken the values over the (optimized) lower and below the (optimized) upper base temperature and cumulated those until the starting date of budbreak or full bloom, respectively. In case of budbreak date calculation the accumulation was started from a parametric term (statistically estimated end of endodormancy), while in case of full bloom starting date estimation the summation was set out at budbreak:

$$
G D D_{i, j}^{b b}=\sum_{\text {start }}^{b b, i} \max \left[\left(\min \left(T_{\text {aver }, j}, T_{u}^{b b}\right)-T_{l}^{b b}\right) ; 0\right]
$$




$$
G D D_{i, j}^{f b}=\sum_{b b}^{f b, i} \max \left[\min \left(\left(T_{a v e r, j}, T_{u}^{f b}\right)-T_{l}^{f b}\right) ; 0\right]
$$

We determined the optimal lower and upper base temperatures separately for the budbreak $\left(T_{l}^{b b}, T_{u}^{b b}\right)$ and full bloom starting dates $\left(T_{l}^{f b}, T_{u}^{f b}\right)$ by minimization such that the lowest root mean square deviation of the observed and predicted dates (standard error, days), the lowest average absolute and the lowest maximum error of predictions (both measured in days) can be achieved.

We computed the mean sum of degree days over the examined years for each variety $i$, for both budbreak and full bloom modules and designated the critical sums of degree days $\left(G D D_{i, c r i t}^{b b}, G D D_{i, c r i t}^{f b}\right.$, respectively).

The model served for prediction of the dates of budburst and full bloom start. In a year, after the starting date, the daily means of temperatures above the lower base temperature (maximized by the difference of the upper and lower base temperature) are accumulated. If the critical value of the respective variety ( $G D D_{i, c r i t}^{b b}$ ) is reached, the date of budburst is indicated and the accumulation for the full bloom starts. If the critical value of the respective variety $\left(G D D_{i, c r i t}^{f b}\right)$ is reached, the starting date of full bloom is indicated.

The daily meteorological data from 1984 to 2010 were taken from the Institute of Research and Extension Service for Fruit Growing at Újfehértó. The data set was completed with phenology data from the same site. (Budbreak dates were available for time interval 1984-1991, only.)

The agroclimatological station is located at the experimental site Újfehértó. The site is one of the most important areas of sour cherry production of Hungary in the region of Nyírség. The region belongs to the continental climatic zone with some Mediterranean and oceanic effects. 1986 was outstandingly hot during the spring and summer, and in 1990 the winter was extremely mild.

We applied the phenology model to study the impact of climate change on budbreak and full bloom starting dates. To this we took the RegCM3.1 (regional) climate model with $10 \mathrm{~km}$ resolution referring to 2021-2050 and with reference period 1961-90, supposed the SRES scenario A1B. The A1B storyline supposes a future world with very rapid economic growth and technological development with an increasing CO2 concentration in the air exceeding 715 ppm up to 2100. Global population peaks in midcentury and declines thereafter. Major underlying themes are convergence among regions, capacity building, and increased cultural and social interactions, with a substantial reduction in regional differences in per capita income. The letter B in A1B refers to the technological emphasis that is balanced across all sources, i.e. not relying too heavily on one particular energy source (IPCC, 2000). The original climate model was developed by Giorgi et al. (1993) and was downscaled at Eötvös Loránd University, Department of Meteorology, Budapest, Hungary (Bartholy et. al., 2009, Torma et. al., 2008).

\subsection{Application for climate change impact study: indicator analysis}

Sour cherry phenophases are variably affected by weather, thus the success of sour cherry growing depends largely on the climatic factors. If during a critical period the weather does not fit for the agrometeorological claims of sour cherry, the yield of the season will be questionable (Szabó, 2007). As the period with a start of 10 days before bloom and during bloom is extremely decisive for the quality and quantity of yield, we focused on this time slice in this study. Several symptoms of climatic change have been observed in Hungary during the last 20 years, as fruit production of the Great Plain was also impaired. Changes have affected the conditions of growing but they have hit hard also the possible future 
production as well. The character and excess of the climate of the region determine the risk of growing. We decided therefore to characterise some climatic indicators of the fruit-growing region during the bloom period with their 10-day pre-bloom period also with the purpose to get ideas referring to the changes of the anticipated future.

Many authors use the method of climatic indicator analysis (Oskam and Reinhard, 1992, Bootsma et al., 2005a,b). Indicators have successfully been applied, amongst others, to field crops, forest and fruit trees, or even for insects and vertebrate animals (Erdélyi, 2009, Erdélyi et al., 2008, Koocheki et al., 2006, Salinger et al., 2005, Eppich et al., 2009). Information on climatic indicators based on historical or climate model estimation output data allows conclusions regarding the suitability of the examined plant or the respective site for growing. We will present the above listed seven climatic indicators adopted for the period 1984-2010, based on observations, and the changes expected for the 2021-2050 period, based on the outputs of RegCM3.1 regional climate model.

\section{Results}

\subsection{Model results}

The optimal lower and upper base temperatures with the optimal starting date (called the statistically optimized end of endodormancy) for budbreak are $2.5^{\circ} \mathrm{C}, 5^{\circ} \mathrm{C}$ and $42^{\text {nd }}$ Julian day of the year (i.e. $11^{\text {th }}$ of February). The optimal lower and upper base temperatures for full bloom start are $3.5^{\circ} \mathrm{C}$ and $19^{\circ} \mathrm{C}$.

The data set was split into two subsets to fit and to validate the model. The root mean square error (standard error), the average (absolute) error and the maximal (absolute) error for fitting are 2.75, 2.25 and 6 days for budbreak while they are 2.82, 2.25 and 6 days for full bloom. The model explains both the budbreak and the full bloom start dates quite effectively (Rsq=0.92, $\mathrm{p}<0.001$; Rsq=0.78, $\mathrm{p}<0.001$ ). The root mean square error (standard error), the average (absolute) error and the maximal (absolute) error of validation of the full bloom starting dates are 2.96, 2.6 and 5 days $(R s q=0.68, p<0.001)$.

With the exception of the years, 1989 and 1990, the error of budbreak estimates did not exceed 3 days in predicting the date of budburst. In the two extreme years, once occurs an error of 6 days with 'Debreceni bötermö' (1989). In 1984 the average error was the lowest, 0.3 day, and in 1989, it was the largest, 5.3 days. The model provides about the same accuracy for all the three varieties.

In 12 years the full bloom start estimations have smaller deviance than 3 days for all the three varieties, however, for the years 1998 and 2004 the model gives the predictions with the highest error (6 days).

Figure 1 represents the budbreak and full bloom start dates of the three sour cherry varieties ('Újfehértói fürtös' (Uf), 'Kántorjánosi' (Kj) and 'Debreceni bötermö' (Db). The dark colors are for the observed dates (budbreak was monitored in between 1984-1991 while full bloom was recorded in between 1984-2010). The lighter colors are for the predicted dates (2021-2050) which were calculated based on the phenology model and RegCM3.1 data. The model predicted that the budbreak dates are expected to shift 12-13 days earlier while full bloom may start 6-7 days earlier than it was observed at the end of the last century. The shifts of dates are significant which is supposedly caused by the changing environment. 


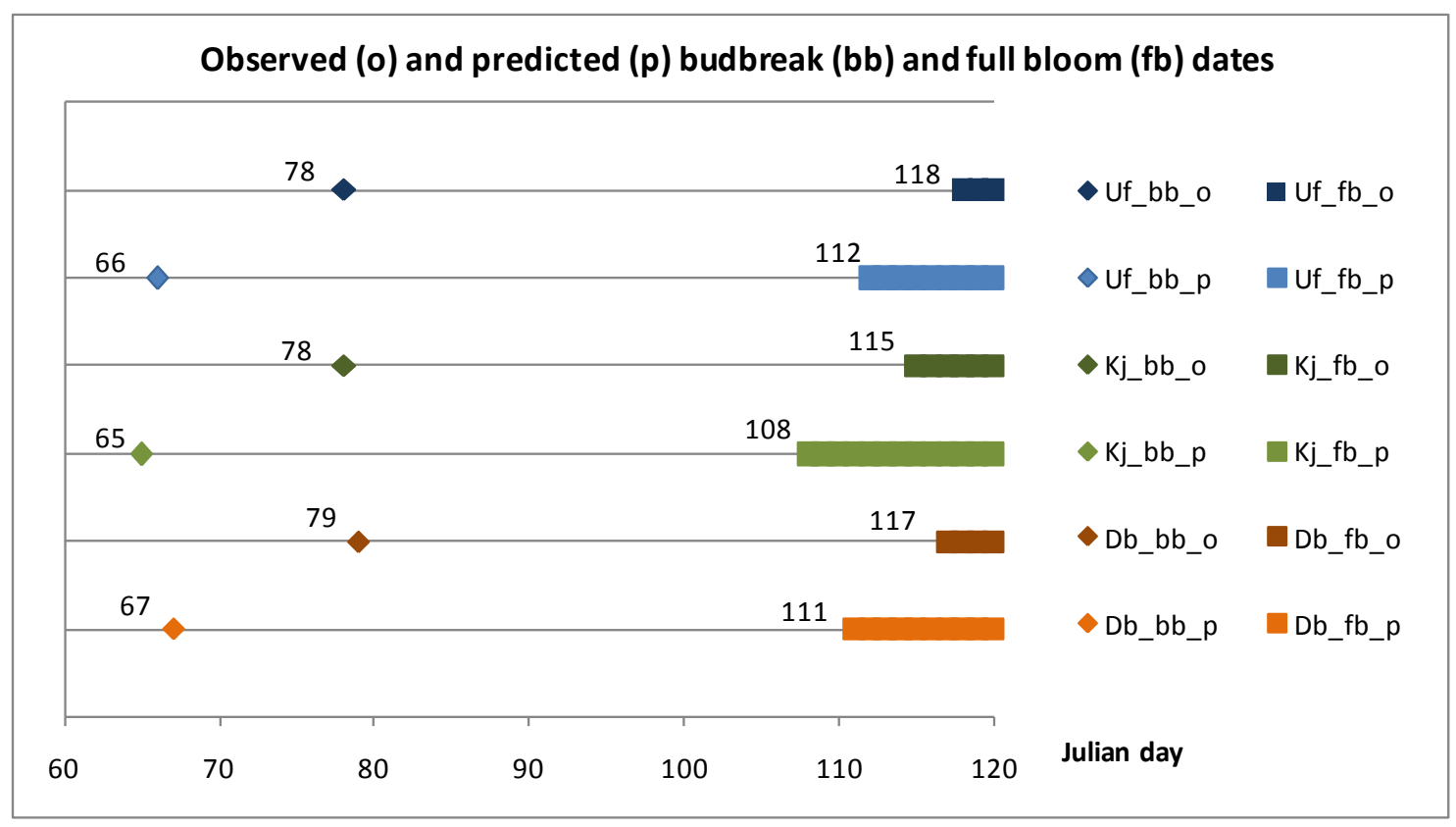

Figure 1. Observed (o) budbreak (bb) (1984-1991) and full bloom (fb) start dates (1984-2010) with the predicted (p) dates (RegCM3.1, 2021-2050) for three sour cherry varieties (Uf, $\mathrm{Kj}, \mathrm{Db}$ )

\subsection{Indicator analysis results}

Seven climatic indicators are considered. First the values of the indicators are calculated for the period of observations (1984-2010). Then the same indicators are calculated regarding the time slice 2021-2050, based on the outputs of RegCM3.1 regional climate model. The future predictions are represented first for the base bloom period (together with its 10-day pre-bloom-period) calculated as the average of the observed endpoints of the bloom periods $\left(101^{\text {st }}-122^{\text {nd }}\right.$ day of year). Supposed that the phenology model predictions of the full bloom starting dates (6-7 days earlier) can be applied, the indicators are calculated for the analogous bloom period which is a period shifted 7-day earlier as the base bloom period.

Table 1. Means of climatic indicators of bloom with 10-day pre-bloom period, Újfehértó calculated based on historical data (1984-2010) and on RegCM3.1 data (2021-2050) assuming no (base bloom) or 7-day phenological shift (analogous bloom). Significant differences were detected if $\mathrm{p}<0.05$.

\begin{tabular}{|l|c|c|c|}
\hline & $\begin{array}{c}1984-2010, \\
\text { observed }\end{array}$ & $\begin{array}{c}2021-2050, \\
\text { base bloom }\end{array}$ & $\begin{array}{c}2021-2050, \\
\text { analogous } \\
\text { bloom }\end{array}$ \\
\hline Number of frosty days $($ days $)$ & $1.1 \dagger \dagger$ & $0.0^{*}$ & $0.1^{*}$ \\
\hline Absolute minimum temperature $\left({ }^{\circ} \mathrm{C}\right)$ & $0.1 \dagger \dagger$ & $6.0^{*} \dagger$ & $4.3^{* \dagger}$ \\
\hline Mean of the daily minimum temperatures $\left({ }^{\circ} \mathrm{C}\right)$ & $6.1 \dagger+$ & $10.9^{*} \dagger$ & $10.0^{* \dagger}$ \\
\hline Number of days with daily mean temperatures above $10^{\circ} \mathrm{C}$ (days) & $15.7 \dagger \dagger$ & $16.1^{* \dagger}$ & $14.2^{*} \dagger$ \\
\hline Mean of maximum temperatures $\left({ }^{\circ} \mathrm{C}\right)$ & $18.5 \dagger \dagger$ & $13.2^{* \dagger}$ & $12.4^{*} \dagger$ \\
\hline Number of days without precipitation $($ days) & 13.6 & 12.1 & 12.1 \\
\hline Number of days with more than $5 \mathrm{~mm} /$ day precipitation (days) & 2.2 & 3.0 & 3.1 \\
\hline
\end{tabular}

significant difference compared to observed* compared to base bloom $\dagger$ compared to analogous bloom $\ddagger$ 
The following statements have been attempted:

- Considering the number of frosty days, the prognosis according to the RegCM3.1 for the period 2021-2050 stated that almost no frosty days are expected.

- The absolute minimum temperature of the period was $0.1{ }^{\circ} \mathrm{C}$ as a mean. The prediction of the RegCM3.1 is much higher thus almost no risk of spring frost is expected.

- The mean of the minimum temperature was $6.1^{\circ} \mathrm{C}$ as recorded, whereas the RegCM3.1 model predicts significantly higher values.

- The number of days with mean temperatures higher than $10^{\circ} \mathrm{C}$ was 16 . According to the RegCM3.1 model, the increase is moderate if there is no phenological shift is assumed. However, in case phenology stages come earlier, a significant decrease is expected.

- The mean of daily maximum temperatures was $18.5^{\circ} \mathrm{C}$ during the 27 years. In some years, it attained even $25^{\circ} \mathrm{C}$, and it was $16^{\circ} \mathrm{C}$ only in others. The RegCM3.1 estimates significantly lower values for 2021-2050, independently from the assumed phenological shift. It means that bloom may of milder temperature condition in the future.

- The number of days without precipitation recorded as 13.6 days, mean of 27 years. The RegCM3.1 model does not predict significantly different results for the future.

- The mean of the number of rainy days with more than $5 \mathrm{~mm}$ precipitation/day was 2.2 days during the recorded period (1984-2010). The prognosis shows a slight, insignificant increment.

Growers are compelled to increase the yields in order to compensate for the increasing costs of production as well as for the irrationally low producer's prices. These efforts are jeopardized by the unstable, changing climate, warming up, unbalanced precipitation as well as the increased frequency and intensity of weather anomalies. Future predictions should be regarded for strategies of adaptation that are needed to be developed.

The model we discussed above should be validated for other regions and/or varieties. Not only the changes of climate and phenology and their impacts but also the possible change of the way of plant respond should be researched. To this regular monitoring and high level, comparable data recording is necessary. Intensive cooperation with growers and decision makers should be improved. With the help of growers' observations the indicators can be associated with certain risky events and thus they can serve the prediction of more detailed future recommendations to prevent damages. In one hand, warmer climate makes possible to grow varieties with higher heat accumulation demand, in other hand more frequent and more serious extreme events increase the risk of production. The symptom of phenology drift calls the attention to the need of new adaptation strategies which are surely unavoidable and urgent (Diós et al., 2009).

\section{Acknowledgements}

The research was sponsored by the following projects: OM-00042/2008, OM-00270/2008, OM00265/2008 and TÁMOP 4.2.1/B-09/1/KMR/-2010-000.

\section{References}

Bartholy, J., Pongracz, R., Torma, Cs., Pieczka, I., Kardos, P., Hunyady, A. (2009): Analysis of regional climate change modelling experiments for the Carpathian basin. International Journal of Global Warming 1, 238-252.

Bindi, M., Miglietta, F., Gozzini, B., Orlandini, S., Seghi, L. (1997a) A simple model for simulation of growth and development in grapevine (Vitis vinifera L.). I. Model description. Vitis 36(2):67-71.

Bindi, M., Miglietta, F., Gozzini, B., Orlandini, S., Seghi, L. (1997b) A simple model for simulation of growth and development in grapevine (Vitis vinifera L.). II. Model validation. Vitis 36(2):73-76. 
Bootsma, A., Gameda, S., McKenney, D.W. (2005a) Impacts of potential climate change on selected agroclimatic indices in Atlantic Canada Canadian Journal of Soil Science Volume 85, Issue 2, May 2005, Pages 329-343.

Bootsma, A., Gameda, S., McKenney, D.W. (2005b) Potential impacts of climate change on corn, soybeans and barley yields in Atlantic Canada Canadian Journal of Soil Science Volume 85, Issue 2, May 2005, Pages 345-357.

Carbonneau, A., Riou, C., Guyon, D., Riom, J., Schneider, C. (1992) Agrométéorologie de la vigne en France. EUROP, Luxembourg, p 168.Bonhomme R (2000) Bases and limits to using "degree-day" units. Eur. J. Agron. 13:1-10, doi:10.1016/S1161-0301(00)00058-7

Carter, T. R., Parry, M. L., Porter, J. H. (2007) Climatic change and future agroclimatic potential in Europe. International Journal of Climatology, 11. 3, P. $251-269$.

Cesaraccio, C, Spano, D., Snyder, R. L, Duce, P. (2004) Chilling and forcing model to predict bud-burst of crop and forest species. Agric. For Meteorol. 126:1-13, doi:10.1016/j.agrformet.2004.03.010

Chuine, I., Cour, P., Rousseau, D. D. (1998) Fitting models predicting dates of flowering of temperate-zone trees using simulated annealing. Plant, Cell and Environment 21: 455-466.

Chuine, I., Cour, P., Rousseau, D. D. (1999) Selecting models to predict the timing of flowering of temperate trees: implications for tree phenology modelling. Plant, Cell and Environment 22:1-13.

Chuine, I. (2000) A unified model for budburst of trees. J Theor Biol 207:337-347, doi:10.1006/jtbi.2000.2178.

Chuine, I., Kramer, K. and Hänninen, H. (2003) Plant development models. In: Schwartz MD (ed) Phenology: an integrative environmental science. Kluwer, Milwaukee, pp 217-235.

Cortázar-Atauri, G.I., Brisson, N. and Gaudillere, J.P. (2009) Performance of several models for predicting budburst date of grapevine (Vitis vinifera L.) Int. J. Biometeorol DOI 10.1007/s00484-009-0217-4).

Diós, N., Szenteleki, K., Ferenczy, A., Petrányi, G., Hufnagel, L. (2009): A climate profile indicator based comparative analysis of climate change scenarios with regard to maize (Zea mays L.) cultures - Applied Ecology and Environmental Research, 7(3): 199-214.

Eppich, B., Dede, L., Ferenczy, A., Garamvölgyi, Á., Horváth, L., Isépy, I., Priszter, Sz., Hufnagel, L. (2009): Climatic effects on the phenology of geophytes - Applied Ecology and Environmental Research, 7(3): 253-266.

Erdélyi, É. (2009) Sensitivity to Climate Change with Respect to Agriculture Production in Hungary (2009) Precision Agriculture '09 Edited by: E.J. van Henten, D. Goense and C. Lokhorst, Wageningen Academic Publisher, p. 559-567.

Erdélyi, É., Boksai, D. Ferenczy, A. (2008) Assessment of climate change impacts on corn and wheat in Hungary, 12th International Eco-Conference, 5th Eco Conference on Safe Food, Novi Sad (Serbia), 24 - 27 September, 2008 pp. 49-55.

Giorgi, F., M. R. Marinucci, and G. T. Bates (1993) Development of a second generation regional climate model (RegCM2) i: Boundary layer and radiative transfer processes, Mon. Wea. Rev., 121, 2794-2813.

Haenninen H. 1991. Does climatic warming increase the risk of frost damage in northern trees? Plant, Cell and Environment 14: 449-454.

Houghton, J. T. (2009) Global Warming. Cambridge University Press, 4th ed. ISBN 978-0-521-70916-3 p. 438.

IPCC (2000) Summary for Policymakers. Emissions Scenarios. A Special Report of IPCC Working Group III. Published for the Intergovernmental Panel on Climate Change. ISBN: 92-9169-113-5

Jones, G. V (2003) Winegrape phenology. In: Schwartz MD (ed) Phenology: an integrative environmental science. Kluwer, Milwaukee, pp 523-540

Jones, G. V, Duchene E., Tomasi D., Yuste, J., Braslavksa, O., Schultz, H., Martinez, C., Boso, S., Langellier, F., Perruchot, C., Guimberteau, G. (2005) Changes in European winegrape phenology and relationships with climate. In: Proceedings of XIV International GESCO Viticulture Congress, Geisenheim, Germany, 23-27 August, 2005, pp 5562 
Koocheki, A. Nasiri, M., Kamali, G.A., Shahandeh, H. (2006) Potential impacts of climate change on agroclimatic indicators in Iran. Arid Land Research and Management. Volume 20, Issue 3, 1 September 2006, Pages 245-259.

Kramer K. 1994. A modelling analysis of the effects of climatic warming on the probability of spring frost damage to tree species in The Netherlands and Germany. Plant, Cell and Environment 17: 367-377.

Kramer K, Friend A, Leinonen I. 1996. Modelling comparison to evaluate the importance of phenology and spring frost damage for the effects of climate change on growth of mixed temperate-zone deciduous forests. Climate Research 7: 31-41.

Moncur, M. W., Rattigan, K., Mackenzie, D. H. \& McIntyre, G. N. (1989). Base temperatures for budbreak and leaf appearance of grapevines. Am. J. Enol. Vitic., 40(1), 21-26.

Oliveira, M. (1998). Calculation of budbreak and flowering base temperatures for Vitis vinifera cv. Touriga Francesa in the Douro Region of Portugal. Am. J. Enol. Vitic. 49(1), 74-78. Proceedings of XIV International GESCO Viticulture Congress, (pp 485-490). Geisenheim, Germany, 23-27 August, 2005.

Oskam, A.J. and A.J. Reinhard (1992) Weather indices of agricultural production in the Netherlands 1948 1989. 2. Grassland. Netherlands Journal of Agricultural Science 40 (1992) 187-205

Reaumur, R. A. F. (1735) Observations du thermomètres, faites à Paris pendant l'année 1735, comparées avec celles qui ont été faites sous la ligne, à l'isle de France, à Alger et quelques unes de nos isles de l'Amérique. Académie des Sciences de Paris 545.

Riou, C. (1994) The effect of climate on grape ripening: application to the zoning of sugar content in the european community. CECACEE- CECA, Luxembourg.

Salinger, M. J. , Sivakumar, M. V. K., Motha, R. (2005) Reducing vulnerability of agriculture and forestry to climate variability and change: Workshop summary and recommendations, Climatic Change Volume 70, Issue 1-2, May 2005, 341-362.

Spano, D., Cesaraccio, C., Duce, P., \& Snyder, R. L. (2002). An improved model for estimating degree days. ISHS Acta Horticulturae 584. VI International Symposium on Computer Modelling in Fruit Research and Orchard Management.

Szabó, T. (2007) Results and economic importance of the North-Eastern Hungarian sour cherry landrace cultivar selection. PhD thesis. Corvinus University of Budapest, 2007. In Hungarian. English abstract: (pp. 31)

http://phd.lib.uni-corvinus.hu/292/3/szabo_tibor_ten.pdf Torma, Cs., Bartholy, J., Pongracz, R., Barcza, Z., Coppola, E., Giorgi, F., (2008): Adaptation and validation of the RegCM3 climate model for the Carpathian Basin. Idojaras $112,233-247$ 